professional growth), of forms of interaction of communication, creative approach to the professional skill.

\title{
References:
}

1. Dubina L.G. Theatrical pedagogy as a component of success of future primary school teachers//Problems of modern pedagogical education: a collection of articles. Kyiv: Pedagogical Press, 2006. Part 2. P. 65.

2. Lemesheva N.A., Kondratyuk N.V. Methods of teaching art: a textbook. Cherkasy. 2014. $124 \mathrm{~s}$.

3. Nichkalo N.G. Theoretical principles of formation and development of subdisciplines in pedagogy//Pedagogical skill as a system of professional and artistic competencies: a collection of materials of pedagogical and artistic readings / Ed. OHM. Father. Chernivtsi: Zelena Bukovyna, 2010. S. 23-31.

4. Rudnytska O.P. Pedagogy of art: searches and prospects//Professional education: pedagogy and psychology: Ukrainian-Polish yearbook. Kiev. Czestochowa. 2000. Vip. 2. P. 232-245.

5. Shevnyuk O. Art disciplines in the reform processes of European integration // Image of a modern teacher. 2006. № 5-6.

DOI https://doi.org/10.30525/978-9934-588-80-8-1.61

\section{РОЗВИТОК ПРОФЕСІЙНОЇ КОМПЕТЕНТНОСТІ ВЧИТЕЛЯ ФІЗИЧНОЇ КУЛЬТУРИ В УМОВАХ ДИСТАНЦІЙНОГО НАВЧАННЯ}

\author{
Онищук С. О. \\ викладач кафедри методики викладання $і$ змісту освіти \\ науково-методичної лабораторії виховання, \\ сочіальної і здоров'язбережувальної освіти \\ Комунальний заклад вищої освіти \\ «Одеська академія неперервної освіти Одеської обласної ради» \\ м. Одеса, Украӥна
}

Формування i розвиток професійної компетентності вчителя виступають сьогодні однією 3 центральних проблем у цілісній системі безперервної освіти. Ї̈̈ актуальність пояснюється необхідністю вирішення протиріччя, що виникло між новими вимогами, запропонованими до педагогічної діяльності вчителя як цілісної особистості, суб’єкта освітнього процесу, здатного до професійно-особистісного 
самовизначення й саморозвитку, конструювання i здійснення гуманістично спрямованих педагогічних систем і технологій, і реальним рівнем професійної компетентності вчителя, його готовності вирішувати завдання школи.

Відповідно до постанови Кабінету Міністрів України «Про встановлення карантину та запровадження посилених протиепідемічних заходів на території із значним поширенням гострої респіраторної хвороби COVID-19, спричиненої коронавірусом SARS-CoV-2» від 22 липня 2020 року № 641, залежно від зони карантину, всі учбові заклади переходять на змішане навчання. А саме вчителі-практики перш за все вчителі фізичної культури, сьогодні, стали перед великою проблемою щодо викладання предмету через дистанційне навчання.

Гострим стало не тільки професійні знання предмету, а й саме вікові труднощі, які стали на заваді про виконання Указу Президента України від 9 лютого 2016 року № 42/2016 Національна стратегія з оздоровчої рухової активності в Україні на період до 2025 року «Рухова активність - здоровий спосіб життя - здорова нація» (далі - Національна стратегія), тому що не можливо онлайн відслідкувати фізичний стан учнів [3, с.10].

Фізичне виховання - важливий засіб фізичного, соціального та духовного розвитку учнівської молоді.

Мета реалізовується комплексом таких навчальних, оздоровчих i виховних завдань:

- формування загальних уявлень про фізичну культуру, їі значення в житті людини, збереження та зміцнення здоров'я, фізичного розвитку;

- розширення рухового досвіду, вдосконалення навичок життєво необхідних рухових дій, використання їх у повсякденній та ігровій діяльності;

- розширення функціональних можливостей організму дитини через цілеспрямований розвиток основних фізичних якостей i природних здібностей;

- формування ціннісних орієнтацій щодо використання фізичних вправ як одного з головних чинників здорового способу життя;

- формування практичних навичок для самостійних занять фізичними вправами та проведення активного відпочинку;

- формування високих моральних якостей особистості [2, с. 7].

Погіршення стану здоров'я учнівської молоді зумовило звернути увагу фахівців у галузі фізичної культури і спорту на цю проблему. Для ii вирішення необхідно приділити увагу підвищенню ефективності 
фізкультурно-оздоровчих програм і нових підходів до викладання предмета, а це прямим чином залежить від професійної компетентностіта професіоналізму вчителів фізичної культури, а також рівня їх підготовленості. Вчитель фізичної культури більш практик своєї справи, а в дистанційному навчанні, коли дитина перебуває вдома одна не можливо дати фізичне навантаження без дорослої особи поряд.

Гострим $є$ той факт, що діти першокласники залишаються без рухливих ігор і взагалі спілкування з однолітками. Замість запам'ятовування фактів та понять учні набуватимуть не компетентності, а ряд захворювань без рухливого досвіду. А нам треба розвивати компетентність - динамічна комбінація знань, умінь, навичок, способів мислення, поглядів, цінностей, інших особистих якостей, що визначає здатність особи успішно соціалізуватися, провадити професійну та/або подальшу навчальну діяльність. Тобто формується ядро знань, на яке будуть накладатись уміння цими знаннями користуватися, а також цінності та навички, що знадобляться випускникам української школи у професійному та приватному житті.

Список компетентностей, яких набуватимуть учні, уже закріплено законом «Про освіту». Він створювався 3 урахуванням «Рекомендації Свропейського Парламенту та Ради Свропи щодо формування ключових компетентностей освіти впродовж життя» [4, с. 84].

Професійна компетентність $\epsilon$ результатом цілеспрямованого впливу післядипломної педагогічної освіти, самоосвіти й розвитку педагогічного професіоналізму на рівні саморозвитку. Вона визначається рівнем, властивим професійній освіті, досвідом та індивідуальними здатностями людини, ії прагненнями до неперервної самоосвіти й самовдосконалення, творчим ставленням до справи, але сьогодення вчителі фізичної культури вперше зіткнулися з навчанням онлайн саме свого предмету.

У реалізації сучасної системи неперервної освіти фахівця в галузі фізичної культури і спорту є також проблема, пов'язана, на наш погляд, iз забезпеченням взаємозв'язку предмета професійної діяльності 3 потребою в постійному вдосконаленні педагогічної майстерності. Такий взаємозв'язок може бути досягнутий в результаті забезпечення подальшого розвитку в учителя фізичної культури таких якостей самоорганізації, як виявлення ініціативи, пізнавальної активності, високого рівня працездатності. Прагнення до самовдосконалення, а також виховання внутрішніх мотивів, що безпосередньо пов'язані 3 професійною діяльністю вчителя. Насамперед це інтерес до процесу навчання і виховання учнів; пошук найбільш ефективних засобів вирішення педагогічних завдань на основі вивчення індивідуальних 
особливостей учнів; бажання і прагнення щодо оволодіння глибокими теоретичними знаннями та передовим досвідом учителів-новаторів; зацікавленість результатом своєї діяльності та потребою в ії апробації [1, c. 48].

\title{
Література:
}

1. Бабешко О. П., Завадич В. М. Чинники оптимізації післядипломної підготовки вчителів фізичної культури // Освіта на Луганщині, № 2, 2004. С. 48-49.

2. Закон «Про загальну середню освіту» від 13.05.1999 // www.edication.gov.ua 3. Концепція 12-річної середньої загальноосвітньої школи // Директор школи. - № 1, 2002. С. 11-15.

3. Навчальна програма 3 фізичної культури для загальноосвітніх навчальних закладів10-11 класи. Рівень стандарту Робоча група, яка здійснила розроблення навчальної програми відповідно до наказу № 451 Міністерства освіти і науки України від 22.03.2017 p.: М. В. Тимчик, Є. Ю. Алексєйчук, В. В. Дерев'янко, В. М. Срмолова, В. О. Сілкова, 2017. 80 с.

4. Онищук С. О. «Впровадження нової української школи на уроках фізичної культури» Науковий Часопис Національного педагогічного університету імені М. П. Драгоманова. Серія 16. Творча особистість учителя: проблеми теорії і практики: збірник наукових праць, 2020. C. $83-87$.

DOI https://doi.org/10.30525/978-9934-588-80-8-1.62

\section{ПЕРСОНОЛОГІЯ В СИСТЕМІ ПІДГОТОВКИ МАЙБУТНІХ УЧИТЕЛІВ}

\author{
Процик Г. М. \\ аспірантка кафедри педагогіки та менеджменту освіти \\ Тернопільський начіональний педагогічний університет \\ імені Володимира Гнатюка \\ м. Тернопіль, Украӥна
}

У період трансформаційних процесів, що відбуваються в освітній галузі, $\epsilon$ необхідністю виокремлення педагогічних персоналій та їх пріоритетних ідей у процесі підготовки майбутніх вчителів.

Із метою вивчення популярності праць вітчизняних і зарубіжних вчених, які застосовуються в навчальному процесі, нами було опитано 16 236 